\title{
Punitive attitudes across geographical areas: Exploring the rural/urban divide in Canada
}

\author{
Kyle Mulrooney \\ Centre for Rural Criminology \\ School of Humanities, Arts, and Social Sciences \\ University of New England \\ AUSTRALIA \\ Jenny Wise \\ Centre for Rural Criminology \\ School of Humanities, Arts, and Social Sciences \\ University of New England \\ AUSTRALIA \\ Contact author - Kyle Mulrooney; kmulroon@une.edu.au; +61 267731940
}

\begin{abstract}
The public is a powerful political actor when it comes to the question of what is to be done about law and order. Therefore, public attitudes towards punishment are of central importance to criminological inquiry. Research in this area has tended towards national (comparative) accounts of 'punitive attitudes' and, in an effort to explore correlates of punitive attitudes, particular sub-groups have been examined often based on certain demographic characteristics such as, for instance, race, gender and/or age. However, very little research exists exploring urban and rural variations in punitive attitudes. Yet, considering that populations may be widely dispersed from central metropolitan and urban areas to rural, regional and very remote areas, it is reasonable to assume that ecological factors and aspects of cultural geography impact upon punitive attitudes. To comparatively examine punitive attitudes across geographical areas, this study draws on cross-sectional data (2004-2015) derived from the Canadian Elections Study (CES). Specifically, the research employs a multidimensional measurement of punitive attitudes by exploring geographic variations in respondents' attitudes towards: (i) the goals of punishment; (ii) the intensity of penal sanctions; and (iii) specified forms of penal sanctions. The sum of the data is then drawn together to develop an index of punitivity, thereby providing a more holistic understanding of punitive attitudes. The findings indicate that on each measure the rural holds significantly greater punitive attitudes than the urban. The article concludes by considering theoretical explanations for these differences, of which future research should attend, with particular attention to the shared political logic between penal populism and political populism and how this contributes to the urban/rural divide as one of the greatest political fault lines in present day politics.
\end{abstract}

Key words: Punitiveness; Public Opinion; Rural; Urban; Canada 


\section{Introduction}

Public reactions to crime occupy a significant amount of scholarly attention. Indeed, the public is understood as being a powerful political actor when it comes to the question of what is to be done about law and order, and therefore their reactions to crime and the attitudes which help to shape these reactions are of central importance (see for example Pratt, 2007). To this end, the opinions of the public have constituted an important area of academic investigation generally and particularly within criminology.

Understanding public attitudes towards crime and punishment is important for a number of reasons. First, in terms of the bigger picture, they provide us with an idea of cultural norms and the perceived role of punishment and crime control in particular societies. Additionally, they can serve as a barometer through which we may, for example, understand how the public feels about the role of the state or levels of satisfaction when it comes to crime and its control (e.g. satisfaction with police/courts). Perhaps most importantly, the large and growing body of work on populism and penal populism more specifically shows that the public is highly influential in guiding crime policy as many politicians are of the belief that penal policies should follow the publics' view (see Green, 2008). While this is perhaps not always in the best interest of sound, empirically informed penal policies, at the same time ignoring public opinion can have serious consequences (e.g. loss of confidence in democracy/criminal justice system). Yet, in order to engage with public perceptions on law and order, we must first grasp how the public feels and therefore it is important to understand the public's values, beliefs and ideals surrounding questions of law and order.

Research in this area has tended towards national accounts of punitive attitudes. For example, Doob and Roberts (1983), pioneers of this type of public opinion research, explored the Canadian public's view of sentencing, while more recently Kury and Obergfell-Fuchs (2008) examined attitudes to punishment and sentencing in the German context. Additionally, comparative research has shown that punitive attitudes differ by country and/or region (see van Dijk, van Kersteren \& Smit, 2007). Furthermore, in an effort to explore correlates of punitive attitudes, particular sub-groups have been examined based on demographic characteristics such as race, gender and/or age (see Dodd, 2017; Applegate, Cullen, \& Fisher, 2002; Sprott, 1999).

Focusing specifically on Canada, research suggests that Canadians have shown support for both punitive and non-punitive measures alike (e.g., Sprott, 1996; Doob et al., 1998; Sprott, 1998; Roberts \& Hough, 2001; Roberts, 2004; Roberts, Crutcher \& Verbrugge, 2007; Roberts \& Sprott, 2008; Meyer \& O’Malley, 2005). For example, a consistent finding in the literature is that the majority of Canadians hold the view that sentencing is too lenient (Doob, 2016). Likewise, Roberts, Crutcher and Verbrugge's (2007) exploration of punitive attitudes in Canada found that while there was strong public support for restorative sentencing, promoting a sense of responsibility in the offender and securing reparation for the crime victim as sentencing goals, over-half of Canadians also supported the use of mandatory minimum sentences.

Comparatively, Canada tends to align with other 'like' jurisdictions. For instance, Burke (2000) and Gerber and Englehardt-Greer (1996) found similar support for mandatory minimum sentences in Australia and the United States respectively. Likewise, Kugler et al's (2013) comparative analysis of cultural differences in punitive attitudes found that, despite 


\section{Punitive attitudes across geographical areas: Exploring the rural/urban divide in Canada- Mulrooney and Wise}

having much more lenient sentencing policies, Americans and Canadians did not differ from each other in sentencing attitudes, and both assigned slightly longer sentences than Germans.

While recent cross-national data on attitudes to punishment is sparse, the International Crime Victimization Surveys indicate that Canada ranks among one of the most punitive countries. For example, in the latest iteration (2004/2005), when asked to suggest the penalty for a "recidivist burglar", Canada ranked fifth highest in support of imprisonment at 44 percent of the 32 countries which responded to this question (van Dijk et al., 2007). By contrast, 51 percent of respondents from England and Wales, 47 percent from the United States, 40 percent from New Zealand and 33 percent from Australia responded similarly (van Dijk et al., 2007). While international comparisons of this nature are difficult to make and limitations to public opinion surveys may contribute to volatility (see Roberts \& Doob, 1989; Gelb, 2008), what we can say for certain is that, in aggregate, Canadians tend to exhibit a 'dual character' of public opinion, showing support for both punitive/non-punitive mechanisms alike. Nevertheless, in general, the country appears to align with other AngloSaxon jurisdictions as the public indicates more support for tough measures than, for instance, many Nordic or European countries (see Pratt \& Eriksson, 2013).

While there is research on punitive attitudes within (and comparing) specific countries, very little research exists exploring intra-national differences and, more specifically, urban and rural variations in punitive attitudes. Yet, considering that populations may be widely dispersed from central metropolitan and urban areas to rural, remote and very remote areas, it is reasonable to assume that ecological factors and aspects of cultural geography impact upon understandings of what is to be done about crime and its control. The limited available research suggests that those who live in rural areas are, in general, less tolerant of many crimes and more likely to strongly support punitive approaches to issues of law and order than people from metropolitan areas (Donnermeyer \& DeKeseredy, 2014; Gelb, 2011; DeKeseredy et al., 2007; Donnermeyer, Jobes \& Barclay, 2006; Weisheit, Falcone, \& Wells, 2006; Walker, Collins \& Wilson, 1987), yet we have little understanding of the attitudes which inform this.

This knowledge is particularly important as nearly a quarter of Canadians live in rural communities and, while shrinking relative to the urban, they are still growing (Cooke, 2018). Furthermore, in addition to the reasons outlined above, understanding these attitudes and how they are formed is especially pertinent when we consider that the urban/rural divide is one of the greatest political fault lines in present day politics (e.g. Trump; Brexit) and politicians appear increasingly attracted to rural communities who may feel disenfranchised yet, together, can exact considerable political power (see Pal \& Choudry, 2007, 2014; Speer \& Jivani, 2017; Lyman, 2016; Tharoor, 2018). For example, research suggests that declining health and rising death rates, fear of cultural displacement and more generalised economic anxiety have primed these communities (across Western nations) to be receptive to populist politics and have been advanced as part of the explanation for President Donald Trump's success with rural voters in the United States (see Goldman et al, 2018; Cox, Lienesch \& Jones, 2017). Likewise, in terms of political allegiance in Canada, Roy, Perrella and Borden (2015) found a clear division with regards to party support according to place of residence in that rural residence tended to support conservative parties. Notably, this finding has been consistent (Bittner, 2007) and held over-time (Adams, 2008; Marland, 2007; Mackinnon, 2007; Gidengil et al., 2006; Blais et al., 2002) with explanations pointing to a variety of factors including, for example, differences within questions of moral traditionalism (Cutler \& Jenkins, 2000). 
Exploring comparative penal attitudes as, at least theoretically, a part of this political fault line is especially relevant given the rise of penal populism in the last three decades and the relationship and similarities this particular form of populism shares with political populism more generally (e.g. anti-elitism) (Unnever \& Cullen, 2010; Brown \& Piscitelli, 2016; Pratt \& Miao, 2017). As argued elsewhere, traditions of penal moderation (see Webster $\&$ Doob, 2015, 2007) and Canadian 'exceptionalism' to wider punitive trends represent a microcosm of a much more encompassing and deeply embedded 'elite political culture' (Mulrooney, 2018; see also MacFarlane, 2017; Adams; 2014; Bricker \& Ibbitson, 2013; Flanagan, 2009: prelude; Owram (1986); Granatstein, 1982), of which its commitment to small-1 liberal values, the institutionalization of these values (e.g., the Supreme Court of Canada), and the structural manifestations of these cultural concerns (e.g., the Canadian Charter of Rights and Freedoms) helped to facilitate, if not mandate, such a moderate penal culture. In recent times, this notion of a liberal elitist political culture has been extended and applied to theoretically explain what is understood as 'Canadian exceptionalism' to the broader political populism that is sweeping many Western liberal democracies (see Kristof, 2016; Liberty moves north, 2016; The last liberals, 2016; Marche, 2016).

As Adams (2014) argues, elite opinion and action in Canada has starkly contrasted with public sentiment on a number of policy issues, including the abolition of the death penalty, the liberalization of abortion and the legalization of same-sex marriage. Yet, overtime, public opinion eventually came to align with that of the elites. However, a small yet growing amount of the public remained unimpressed with the elitist drift of the country (Bricker \& Ibbitson, 2013; Adams, 2014). This anti-elitist backlash came to the fore with the rise of a new 'right-wing' populist style of conservativism ushered in by the Conservative Party of Canada between 2005-2015. As Webster and Doob (2015) suggest, this new government represented a completely different 'breed' of conservatism that Canada had never seen before (p. 3) and re-organized Canada's political landscape, not least in matters of crime and justice. While this government's populist approach received significant resistance in the media, legal and, to a lesser extent, political spheres they notably remained in government for a decade and, most importantly, shattered the long-standing political consensus centred on liberal elitism; the genie of public emotions towards crime, and indeed politics more generally, was let out of the bottle (Loader, 2006).

With this in mind, the urban/rural political divide and the rise of a broader political populism warrants a closer inspection. This macro generalization of a liberal 'political culture' and 'penal culture' may be significantly challenged when exploring attitudes on a micro-level where individual identities and values may be shaped by more immediate cultural norms and values and are therefore outside, and perhaps at odds with, the broader national psyche crafted in large part by liberal elites. Add to this the evidence that people who live in rural communities tend to support conservative parties and that those who support conservative parties tend to hold more punitive attitudes (Tonry, 1999; Jacobs \& Helms, 1996; Beckett \& Western, 2001; Smith, 2004; Yates \& Fording, 2005; Loader \& Sparks, 2016) and we can hypothesise that the 'rural voice' in Canada will not only contrast starkly to the elite led traditions of penal moderation but also to their urban counterparts.

To this end, this article marks an initial foray into these theoretical concerns, filling a gap in the literature, by first examining whether rural communities in Canada do in fact have a greater affinity for punitive attitudes and considering the implications of these findings in 


\section{Punitive attitudes across geographical areas: Exploring the rural/urban divide in Canada- Mulrooney and Wise}

terms of causal mechanisms. The answers to such questions are vitally important for engaging with these communities on issues of law and order and beyond.

\section{Conceptualizing punitive attitudes}

Punitiveness or punitivity has received a lot of criticism for being a loosely defined and highly under-theorized concept which has been over-applied and, at times, misapplied in the extant literature (see Matthews, 2005). Much of these issues stem from a lack of clarity over what exactly it is we are talking about when we say punitiveness, as well as the absence of empirically and theoretically informed attempts to measure the concept. Kury, Kania and Obergfell-Fuchs (2004) provide a good starting point by suggesting that we employ an "onion model" which differentiates between three "skins" or layers of punitivity on a macro, meso and micro level. The macro level refers to those social discourses and cultural sensibilities which inform debates that tend to play out in the media, as well as political conversations around crime and punishment. From the perspective of comparative criminal justice research, here we can consider those macro comparisons of penal cultures of, for example, American punitiveness versus Dutch tolerance or Nordic exceptionalism (see Downes, 1988; Pratt \& Eriksson, 2013).

On the meso-level are those aspects which tend to concern the administration of justice and can include issues related to the number or length of prisons sentences handed down by judges or the role of prosecutors (see Pfaff, 2017). Here we are really concerned with the specific actions of state actors (such as the police, prosecutors or the judiciary) when it comes to matters of law and order. The micro-level, which is the focus of this article, concerns itself with attitudinal orientations towards crime and punishment in the general populace. That is, if the macro-level is concerned with the punitivity of Canada as a jurisdiction, and the meso-level with that of the Canadian judiciary, then the micro level attends to an individual Canadian's need for punishment and is therefore interested in their values, beliefs and ideals surrounding questions of what is to be done about law and order.

A large and growing body of international literature has sought to measure punitive attitudes in a variety of ways. Early work in this vein tended towards very general questions, therefore providing a very incomplete understanding of what is in fact a complex construct (see Doob \& Roberts, 1988). For instance, asking respondents whether sentences handed down by the judiciary are "too harsh", "not harsh enough" or "just about right" is problematic, not least because respondents tend to have the worst kinds of offenders in mind when answering this question (Gelb, 2008; Hough \& Roberts, 2002).

As the field developed, in an effort to capture the complexity of these attitudes, scholars began to ask more specific questions (Unnever, Cullen \& Roberts, 2005). Some have focused on attitudes towards the goals of punishment which refers to what an individual feels the criminal justice wants to accomplish when it comes to responding to crime; for example, to seek vengeance, to incapacitate, to deter and/or to rehabilitate (see Doob \& Roberts, 1988; Pfeiffer, Windzio \& Kleimann, 2005; Roberts et al., 2009). In this case, those who support retribution, incapacitation or deterrence for a particular crime/offender would be seen as more punitive than those who support rehabilitative ideals.

Research has also considered specific forms of penal sanctions by determining one's support, or lack thereof, for a means of punishment for a particular crime/offender such as, for example imprisonment, community sanctions etc. (see Young, 1992; Grasmick, Bursik \& 
Blackwell, 1993; Unnever, Cullen \& Applegate, 2005; Robbers, 2006; Ramirez, 2013) and/or along a continuum of penal sanctions (see Doob \& Roberts, 1988; Hough \& Roberts, 2002; Kury \& Obergfell-Fuchs, 2008). By this measure, those in support of imprisonment and/or with very little support of probation would be seen as punitive and vice versa.

Additionally, scholars have considered the intensity of penal sanctions by measuring one's desire to see offenders punished. Quantitatively this is concerned with desires for the number of people punished as well as issues relating to the length of prisons sentences or cost of fines, while qualitatively the concern is with the desired conditions of punishment (see King \& Maruna, 2009). In this case, those who support longer and more austere forms of punishment for a wider variety of offenders, whether this be in terms of offence type or offender specific characteristics, would be seen as more punitive than those who do not. Finally, studies have tended to explore sentencing specifically by determining an individual's support for punitive and non-punitive sentencing options for a particular crime/offender (see Applegate \& Cullen, 1996; Roberts \& Hough, 2005, Mitchell \& Roberts, 2012). By this measure, those in favour of the death penalty, three-strikes policies or mandatory minimum sentences, for example, would be seen as punitive, while those who supported house-arrest or parole, for instance, would be seen as non-punitive in their attitudinal orientation.

Nevertheless, while research has broadened its scope by highlighting particular crimes/offenders and examining more specific facets of punitiveness (e.g. intensity of sanctions), Adriaenssen and Aertsen (2015) argue that, on their own, these measures can tell us very little as they merely shed light on one or two elements of punitive attitudes. Rather, the authors advance a multidimensional concept of punitive attitudes which is concerned with the public's attitudes across these four key indicators: (i) an attitude towards the goals of punishment; (ii) specified forms of penal sanctions; (iii) the intensity of penal sanctions; and (iv) specific sentencing policies.

Through this multidimensional understanding of punitive attitudes, researchers may identify specific attitudes across these four dimensions providing a much more nuanced measurement of punitive attitudes. For instance, depending on the answers given, participants may hold consistent (non)-punitive attitudes across all four domains or some mix by, for instance, feeling that the goal of the criminal justice system should be concerned with rehabilitation while also showing strong support for the death penalty as a particular form of punishment for certain offenders (e.g. those who have murdered). Perhaps most importantly, when taken together, the sum of the data may be drawn together to develop an index of punitivity thereby providing a more holistic understanding of punitive attitudes.

\section{Methodology}

To comparatively examine punitive attitudes across rural and urban geographical areas, this study draws on cross-sectional data derived from the Canadian Elections Study (CES). The CES is a large body of survey data that has been gathered and analysed for over five decades (1965-present). The main objective of the CES is to explain what makes people decide to vote (or not to vote), and, if they do, what makes them decide to support a given party or candidate, and why parties gain or lose ground from one election to another.

Nevertheless, the CES probes a significant number of topics. For example, the 2006 CES encompassed nearly 6,700 variables including demographic characteristics and locational data, as well as questions dealing with topics from political interests and political 


\section{Punitive attitudes across geographical areas: Exploring the rural/urban divide in Canada- Mulrooney and Wise}

efficacy to issue orientations and media exposure, among many others. CES surveys are randomly administered to a national sample, predominately over the telephone but also via mail-back survey and, more recently, the internet, to eligible Canadian voters during and after a federal election (and/or referendum). The robust sample size of the CES along with the breadth of topics explored allows for a representative, detailed and sophisticated analysis of a variety of variables, including an examination of different sub-groups (e.g. male/female). However, it is important to note that while the CES provides a representative sample of the Canadian population, certain regions and provinces are better represented while others, such as the Yukon and Northwest Territories, remain less well represented due to the low inclusion of cases from these regions. For a more detailed overview of the CES see Kanji, Bilodeau and Scotto (2012).

The data utilized in this paper draws on the 2004, 2008, 2011 and 2015 CES. This time period was chosen for two reasons. First, the choice was a practical one. Given the CES was run four times in this ten-year time period, it was determined that the cross-sectional data was robust and allowed for the exploration of contemporary attitudes towards punishment. Second, and perhaps most importantly, this decade is particularly relevant as the rise of the Conservative Party of Canada (2006-2015) to power saw (penal) populism dominate the political arena in a way never before seen in Canadian history (Webster \& Doob, 2015; Mulrooney, 2018). Thus, in contrast to a long-standing history of elitism wherein penal policy making was the purview of elites, law and order was at the forefront a public and political thought and discourse during this time-period (see Mulrooney, forthcoming).

Closely connected to this, a ten-year period is also manageable when it comes to contextualizing the data in terms of socio-political changes that may have occurred, as well as theorizing explanations with respect to the results. For instance, we could hypothesise that a decade of law and order discourse from the federal government would see Canadian's attitudes towards punishment harden or, as discussed below, consider how the current wider political climate may shape the results. Nevertheless, while this methodological choice allowed for a purposeful, theoretical and contextually informed analysis, its primary limitation is that it lacks the historical data from which to make comparisons (i.e. rural/urban attitudes prior to these changes which occurred in the political arena).

While the publicly available CES is predominately utilized by political scientists there is much untapped data of interest to criminologists. Perhaps most importantly, for our purposes here, the data set allows for cross-sectional explorations of punitive attitudes and comparisons of these attitudes by geographical area. Specifically, the CES not only collects data on the province in which respondents live, but also the Federal electoral districts in which they reside. Federal electoral districts are geographically bound constituencies that elect Members of Parliament to Canada's House of Commons every election.

Drawing on Federal electoral districts we are able to make comparisons across rural and urban geographical areas by organizing these districts accordingly. The more difficult issue posed by such a classification is operationalizing the rural and the urban. Those exploring this dichotomy have pursued a number of avenues. For instance, Farmers Forum, an independent farm newspaper exploring issues that affect farm life in the province of Ontario, considered any Federal electoral district with fewer than 100 people per square kilometre rural. In contrast, Statistics Canada, the countries national statistical office, recently developed a much more complex remoteness index which prioritized accessibility and included the summation of the sizes of the population centres that can be reached by 
community, a measure of the proximity of each population centre to community and set travel time from the community (Alasia et al, 2017).

Given the available information, we were required to develop our classification on the former, and indeed most readily employed classification which is based on population density. Statistics Canada data on "Population and Dwelling Count" derived from the Canadian Census conveniently provides population density per square kilometre for each Federal electoral district. As our intention was to develop a meaningful comparison between the rural and the urban, instead of creating an arbitrary cut-off point where rural tends to be anything from below 100 people per $\mathrm{km}^{2}$ to 400 people per $\mathrm{km}^{2}$ and everything in between, we developed a third category known as 'rurban' to deal with the few ridings that pose a particularly unique challenge.

The rurban category included those ridings with between $150-300$ people per $\mathrm{km}^{2}$. These ridings are an eclectic mix of the rural and the urban in that, thanks to population growth and city expansion, they include populated urban areas (e.g. commuter suburbs) but also a vast spread of semi-populated rural land. Thus, for example, those who work in Toronto, Ontario commuting from the suburban riding of Durham Region (Ontario) may well see themselves as urban, yet farmers, long-established families and/or those outside of suburban housing developments in these communities may well strongly disagree with this assessment. While the rurban group was included in the preliminary analysis, it is not presented in these results because the main focus of this article is on comparisons between the rural and the urban and there were few significant differences to report within this category. Yet, identifying these relatively small number of ridings (12 to 16, depending on the year) left us with a more reliable comparison of rural and urban communities, the former including those with less than 150 people per $\mathrm{km}^{2}$ and the latter those with more than 300 people per $\mathrm{km}^{2}$.

It is important to note that, as the CES data drawn on spanned 2004-2015, these classifications changed slightly as ridings were re-organized, new electoral districts came into effect and calculations were made using the closest available census data on population density. Thus, for the 2004 and 2008 data set the variables were created using the 2003 Representation Order which included 308 Federal electoral districts and the 2006 Census population data; the 2011 data set drew on the 2003 Representation Order and the 2011 Census data; and, finally, the 2015 data set drew on the most recent 2013 Representation Order, which now included 338 Federal electoral districts, and the 2016 Census population data. Such changes led to very few differences between the data sets in terms of rural/rurban/urban variables: in 2004 and 2008 there were 150 rural ridings, 16 rurban ridings and 142 urban ridings; in 2011 this changed to 146, 16 and 146 respectively; and, finally, in 2015 this changed to 150,12 and 176 respectively. Despite these changes, there are still clear sub-categories of rural, rurban and urban from which to undertake a detailed and sophisticated comparative analysis.

Once the classification variables were operationalised and developed, the next step was to determine the data relevant to punitive attitudes, with particular consideration given to the multi-dimensional definition of punitive attitudes outlined above. As we were drawing on an existing data set, the trade-off for robust cross-sectional data meant that the questions asked were developed without this multi-dimensional definition in mind. Nevertheless, with the data available, we were able to draw on three questions to serve as proxies for the dimensions of punitiveness. The first question asked respondents: What is the BEST way to 


\section{Punitive attitudes across geographical areas: Exploring the rural/urban divide in Canada- Mulrooney and Wise}

deal with young offenders who commit violent crime? With this question, we are able to grasp what the respondents think the goal of punishment should be in this case (e.g. to punish or to rehabilitate) as well as something about their support for punitive and non-punitive sentencing options more broadly.

In 2004 and 2008 respondents were given the following choices: (1) give them tougher sentences; (2) spend more rehabilitating them; (3) focus on parents, home life, community values, morals; (4) enrol them in an army/boot camp; (5) preventative measures, e.g., education; (6) depends on the situation; (7) both 1 and 1; and (8) don't know. While this question was also asked in 2011 and 2015, respondents were confined to the choices of (1) give them tougher sentences; (2) spend more on rehabilitating them; and (3) not sure.

Subsequently, as the intention was to explore comparative variations with respect to the goals of sentencing, the response categories were collapsed into "Punish" and "Prevent/Rehabilitate" with the former including those that sought to punish (e.g. give them tougher sentences and enrol them in army/boot camp) and latter including those with a preference for rehabilitative and preventative measures (e.g. spend more rehabilitating them; focus on parents, home life, community values, morals; preventative measures). "Not sure" was excluded due to the low response in this category.

The second question asked respondents to indicate their agreement (or lack thereof) with the following statement: We must crack down on crime, even if that means that criminals lose their rights. The response categories of (1) strongly agree; (2) agree; (3) disagree; (4) strongly disagree; and (5) not sure were collapsed into (1) agree and (2) disagree in order to clearly differentiate between those who were in support of this statement and those who indicated they were against the statement, while "not sure" was excluded given the low response in this category.

This question provides insight into the respondents' preferences around the intensity of penal sanctions in that agreement/disagreement with this statement would indicate whether respondents were comfortable with limiting individual rights in the name of increasing the certainty of punishment. Finally, the third question posed asked respondents a classic question which allows us to measure support for a specific form of penal sanction and specific sentencing option: Do you favour or oppose the death penalty for people convicted of murder? The response categories for this question included (1) favour; (2) oppose; and (3) not sure. Notably, the 2004, 2006, 2008 and 2011 data reported a "depends" category if volunteered by the respondent (e.g. not a given option). For the reasons outlined above, the response categories were collapsed into (1) favor and (2) oppose.

Additionally, the results of the individual questions were combined to develop a punitivity index. To give equal weighting, the questions were adjusted to provide a score $1-$ 2. What is the best way to deal with young offenders who commit violent crime? was coded as punish (1) and prevent/rehabilitate (2). We must crack down on crime, even if that means that criminals lose their rights was coded as agree (1) and disagree (2). Finally, do you favour or oppose the death penalty for people convicted of murder? was recoded favour (1) and oppose (2). Scores were then summed between 3-6 and the sample was divided into a bi-modal distribution. Low scores indicate a more punitive attitude and high scores a less punitive attitude. 
In order to gather our sample from the data set, participants had to have answered the punitivity questions and revealed their geographical information. Notably, to run the puntivity index participants must have answered all three questions in a given year and therefore those who did not were excluded from the sample. The total sample drawn on for this study included 4605 participants who answered all three punitivity questions, of which 2518 were rural and 2087 were urban.

All analyses were conducted using IBM SPSS Statistics Version 25. Descriptive statistics were conducted for all variables of interest. For each question used in the punitivity index, crosstabs analysis were conducted with the residential location of the participants as the dependent variable. Chi-square tests for independence and tests for linear trends were conducted and significance was set at $p=.05$. A logistic regression analysis was performed to determine the independent predictors of punitivity.

\section{Findings}

\section{Punitive Attitudes in Canada}

\section{The goals of punishment}

Canadians are polarized on the best way to deal with young offenders who commit violent crime. For instance, in both 2004 and 2011 nearly 54 percent of Canadians supported tougher sentences in contrast to 46 percent who preferred a preventative/rehabilitative approach (see Table 1). However, the trendline indicates a significant change in the responses of Canadians to this question over time with growing support for a rehabilitative approach. For example, while in 2004 only 46.3 percent of respondents supported rehabilitation this grew to 59.3 percent by 2015 . Taken together, over the decade slightly more Canadians favoured a preventative/rehabilitative approach (51.3\%) over a punitive one (48.9\%).

Table 1

\begin{tabular}{|c|c|c|c|c|c|c|c|}
\hline \multirow{2}{*}{\multicolumn{3}{|c|}{$\begin{array}{l}\text { What is the best way to deal with } \\
\text { young offenders who commit violent } \\
\text { crime? }\end{array}$}} & \multicolumn{4}{|l|}{ YEAR } & \multirow{3}{*}{$\begin{array}{l}\text { Total } \\
2242\end{array}$} \\
\hline & & & \multirow{2}{*}{$\begin{array}{l}2004 \\
636\end{array}$} & \multirow{2}{*}{$\begin{array}{l}2008 \\
662\end{array}$} & \multirow{2}{*}{$\begin{array}{l}2011 \\
578\end{array}$} & \multirow{2}{*}{$\begin{array}{l}2015 \\
366\end{array}$} & \\
\hline \multirow{4}{*}{$\begin{array}{l}\text { All } \\
\text { participants }\end{array}$} & \multirow[t]{2}{*}{ Tougher sentences } & $\mathrm{n}$ & & & & & \\
\hline & & $\%$ & $53.7 \%$ & $46.0 \%$ & $53.4 \%$ & $40.7 \%$ & $48.9 \%$ \\
\hline & \multirow[t]{2}{*}{ Rehabilitation } & $\mathrm{n}$ & 548 & 776 & 505 & 534 & 2363 \\
\hline & & $\%$ & $46.3 \%$ & $54.0 \%$ & $46.6 \%$ & $59.3 \%$ & $51.3 \%$ \\
\hline \multirow[t]{2}{*}{ Trend $<.001$} & \multirow[t]{2}{*}{ Total } & $\mathrm{n}$ & 1184 & 1438 & 1083 & 900 & 4605 \\
\hline & & $\%$ & $100.0 \%$ & $100.0 \%$ & $100.0 \%$ & $100.0 \%$ & $100.0 \%$ \\
\hline
\end{tabular}

The intensity of penal sanctions

Canadians appear strongly in favour of cracking down on criminals over ensuring their rights. Indeed, in 2004, 75.3 percent of respondents agreed with this statement (see Table 2). Over the decade we are provided with a similar picture as 67.3 percent of Canadians support cracking down on crime even if it meant limiting the rights of offenders compared to 32.7 percent of those who disagreed. Notably, however, there has been a significant trend of Canadians disagreeing with this statement. For example, agreement with 


\section{Punitive attitudes across geographical areas: Exploring the rural/urban divide in Canada- Mulrooney and Wise}

this statement fell by nearly 20 percent to a low of 56.6 percent by 2015 . Nevertheless, a majority of Canadians (56.6\%) still agreed with cracking down on criminals over ensuring their rights in 2015 (43.4\%).

\section{Table 2}

\begin{tabular}{|c|c|c|c|c|c|c|c|}
\hline \multirow{2}{*}{\multicolumn{3}{|c|}{$\begin{array}{l}\text { We must crack down on crime, even if } \\
\text { that means that criminals lose their } \\
\text { rights }\end{array}$}} & \multicolumn{4}{|l|}{ YEAR } & \multirow[t]{2}{*}{ Total } \\
\hline & & & 2004 & 2008 & 2011 & 2015 & \\
\hline \multirow{4}{*}{$\begin{array}{l}\text { All } \\
\text { participants }\end{array}$} & \multirow[t]{2}{*}{ Agree } & $\mathrm{n}$ & 892 & 1009 & 689 & 509 & 3099 \\
\hline & & $\%$ & $75.3 \%$ & $70.2 \%$ & $63.6 \%$ & $56.6 \%$ & $67.3 \%$ \\
\hline & \multirow[t]{2}{*}{ Disagree } & $\mathrm{n}$ & 292 & 429 & 394 & 391 & 1506 \\
\hline & & $\%$ & $24.7 \%$ & $29.8 \%$ & $36.4 \%$ & $43.4 \%$ & $32.7 \%$ \\
\hline \multirow[t]{2}{*}{ Trend $<.001$} & \multirow[t]{2}{*}{ Total } & $\mathrm{n}$ & 1184 & 1438 & 1083 & 900 & 4605 \\
\hline & & $\%$ & $100.0 \%$ & $100.0 \%$ & $100.0 \%$ & $100.0 \%$ & $100.0 \%$ \\
\hline
\end{tabular}

\section{Specified forms of penal sanctions}

The data indicates that significantly more Canadians oppose the death penalty in all years the question was asked. For example, as Table 3 indicates, between 2004-2015 opposition to the death penalty ranged from a high of 58.2 percent in 2011 to a low of 54 percent in 2004 with support ranging from 41.8 percent and 46 percent respectively. Taken together, the data over the decade shows that 56.2 percent of Canadians oppose the death penalty, as opposed to 43.8 percent who support this sanction. Notably, over the period from 2004 to 2015 there has been a significant downward trend in the proportion who favour the death penalty $(\mathrm{p}<.05)$.

Table 3

\begin{tabular}{|c|c|c|c|c|c|c|c|}
\hline \multirow{2}{*}{\multicolumn{3}{|c|}{$\begin{array}{l}\text { Favour or oppose the death } \\
\text { penalty }\end{array}$}} & \multicolumn{4}{|l|}{ YEAR } & \multirow{3}{*}{$\begin{array}{l}\text { Total } \\
2017\end{array}$} \\
\hline & & & \multirow{2}{*}{$\begin{array}{l}2004 \\
545\end{array}$} & \multirow{2}{*}{$\begin{array}{l}2008 \\
639\end{array}$} & \multirow{2}{*}{$\begin{array}{l}2011 \\
453\end{array}$} & \multirow{2}{*}{$\begin{array}{l}2015 \\
380\end{array}$} & \\
\hline \multirow{4}{*}{$\begin{array}{l}\text { All } \\
\text { participants }\end{array}$} & \multirow[t]{2}{*}{ Favour } & $\mathrm{n}$ & & & & & \\
\hline & & $\%$ & $46.0 \%$ & $44.4 \%$ & $41.8 \%$ & $42.2 \%$ & $43.8 \%$ \\
\hline & \multirow[t]{2}{*}{ Oppose } & $\mathrm{n}$ & 639 & 799 & 630 & 520 & 2588 \\
\hline & & $\%$ & $54.0 \%$ & $55.6 \%$ & $58.2 \%$ & $57.8 \%$ & $56.2 \%$ \\
\hline \multirow[t]{2}{*}{ Trend .04 } & \multirow[t]{2}{*}{ Total } & $\mathrm{n}$ & 1184 & 1438 & 1083 & 900 & 4605 \\
\hline & & $\%$ & $100.0 \%$ & $100.0 \%$ & $100.0 \%$ & $100.0 \%$ & $100.0 \%$ \\
\hline
\end{tabular}

\section{Punitivity Index}

The data is consistent with the notion that Canadians have mixed views on questions of punishment, showing support for punitive and non-punitive measures alike. However, when taken together, the punitivity index presented in Table 4 indicates that Canadians are, on the whole, significantly more punitive than not, with 54.7 percent of Canadians falling into the more punitive category and 45.3 percent into the less punitive category in the bimodal distribution. Nevertheless, the trendline suggests that Canadians are becoming less punitive overtime, with the more punitive category dropping from a high of 59.4 percent in 2004 to a low of 47.2 percent in 2015, and the less punitive category rising from 40.6 percent to 52.8 percent respectively. As support/opposition to the death penalty shows only small 
changes, this drop in punitiveness is largely driven by more support for preventative/rehabilitative approaches to dealing with violent young offenders and especially by disagreement with the statement that "we must crack down on criminals even if it means limiting their rights".

Table 4

\begin{tabular}{|c|c|c|c|c|c|c|c|}
\hline \multirow{2}{*}{\multicolumn{3}{|c|}{ Punitivity index }} & \multicolumn{4}{|l|}{ YEAR } & \multirow{3}{*}{$\begin{array}{l}\text { Total } \\
2517\end{array}$} \\
\hline & & & \multirow{2}{*}{$\begin{array}{l}2004 \\
703\end{array}$} & \multirow{2}{*}{$\begin{array}{l}2008 \\
793\end{array}$} & \multirow{2}{*}{$\begin{array}{l}2011 \\
596\end{array}$} & \multirow{2}{*}{$\begin{array}{l}2015 \\
425\end{array}$} & \\
\hline All & \multirow{2}{*}{$\begin{array}{l}\text { More } \\
\text { punitive }\end{array}$} & $\mathrm{n}$ & & & & & \\
\hline \multirow[t]{3}{*}{ participants } & & $\%$ & $59.4 \%$ & $55.1 \%$ & $55.0 \%$ & $47.2 \%$ & $54.7 \%$ \\
\hline & \multirow{2}{*}{$\begin{array}{l}\text { Less } \\
\text { punitive }\end{array}$} & $n$ & 481 & 645 & 487 & 475 & 2088 \\
\hline & & $\%$ & $40.6 \%$ & $44.9 \%$ & $45.0 \%$ & $52.8 \%$ & $45.3 \%$ \\
\hline \multirow[t]{2}{*}{ Trend $<.001$} & \multirow[t]{2}{*}{ Total } & $\mathrm{n}$ & 1184 & 1438 & 1083 & 900 & 4605 \\
\hline & & $\%$ & $100.0 \%$ & $100.0 \%$ & $100.0 \%$ & $100.0 \%$ & $100.0 \%$ \\
\hline
\end{tabular}

\section{Comparing Punitive Attitudes: The Urban and the Rural}

\section{The goals of punishment}

There was a significant relationship between where people live and their attitudes towards punishment for violent young offenders. Namely, it appears that people from rural areas are more likely to support punitive measures for young offenders. The cross-tabulation revealed key differences in support for tougher sentences and rehabilitation as evidenced by the difference in percentages between the rural and urban classifications (see Tables 5, 6 and 7). For instance, in 201158.3 percent of rural respondents preferred punishment for young violent offenders in contrast to 47.6 percent of urban respondents. Taken together, over the decade we see similar differences with 52.1 percent of rural respondents favouring punishment in contrast to 44.5 percent of urban respondents.

As outlined above, the cross-sectional data suggest that, as a whole, support for punishment has fallen slightly overtime; though when disaggregated we see that this drop has been consistent in the urban classification and more sporadic in the rural (see Table 5 and 6). Indeed, there is no significant trend in the rural classification while the urban classification shows a significant trend towards less punitive attitudes with growing support for a rehabilitative approach to dealing with violent young offenders.

For example, in the rural classification, support for punishment remained relatively stable, seeing a dip below 50 percent for the first time in 2008 and climbing up again in 2011 (58.3\%), before reaching its lowest point in 2015 (47\%). Conversely, 52.1 percent of urban respondents favoured punishment in 2004 and this figure has consistently dropped with only 35.7 percent favouring punishment in 2015. Subsequently, on this dimension, the gap between the urban and the rural has grown considerably. 
Punitive attitudes across geographical areas: Exploring the rural/urban divide in CanadaMulrooney and Wise

\section{Table 5}

\begin{tabular}{|c|c|c|c|c|c|c|c|}
\hline \multirow{2}{*}{\multicolumn{3}{|c|}{$\begin{array}{l}\text { What is the best way to deal with } \\
\text { young offenders who commit violent } \\
\text { crime? }\end{array}$}} & \multicolumn{4}{|l|}{ YEAR } & \multirow{3}{*}{$\begin{array}{l}\text { Total } \\
1313\end{array}$} \\
\hline & & & \multirow{2}{*}{$\begin{array}{l}2004 \\
369\end{array}$} & \multirow{2}{*}{$\begin{array}{l}2008 \\
418\end{array}$} & \multirow{2}{*}{$\begin{array}{l}2011 \\
339\end{array}$} & \multirow{2}{*}{$\begin{array}{l}2015 \\
187\end{array}$} & \\
\hline \multirow{4}{*}{$\begin{array}{l}\text { Rural } \\
\text { participants }\end{array}$} & \multirow[t]{2}{*}{ Tougher sentences } & $\mathrm{n}$ & & & & & \\
\hline & & $\%$ & $54.9 \%$ & $48.2 \%$ & $58.3 \%$ & $47.0 \%$ & $52.1 \%$ \\
\hline & \multirow[t]{2}{*}{ Rehabilitation } & $\mathrm{n}$ & 303 & 449 & 242 & 211 & 1205 \\
\hline & & $\%$ & $45.1 \%$ & $51.8 \%$ & $41.7 \%$ & $53.0 \%$ & $47.9 \%$ \\
\hline \multirow[t]{2}{*}{ Trend .23 } & \multirow[t]{2}{*}{ Total } & $\mathrm{n}$ & 672 & 867 & 581 & 398 & 2518 \\
\hline & & $\%$ & $100.0 \%$ & $100.0 \%$ & $100.0 \%$ & $100.0 \%$ & $100.0 \%$ \\
\hline
\end{tabular}

Table 6

\begin{tabular}{|c|c|c|c|c|c|c|c|}
\hline \multirow{2}{*}{\multicolumn{3}{|c|}{$\begin{array}{l}\text { What is the best way to deal with } \\
\text { young offenders who commit violent } \\
\text { crime? }\end{array}$}} & \multicolumn{4}{|l|}{ YEAR } & \multirow{3}{*}{$\begin{array}{l}\text { Total } \\
929\end{array}$} \\
\hline & & & \multirow{2}{*}{$\begin{array}{l}2004 \\
267\end{array}$} & \multirow{2}{*}{$\begin{array}{l}2008 \\
244\end{array}$} & \multirow{2}{*}{$\begin{array}{l}2011 \\
239\end{array}$} & \multirow{2}{*}{$\begin{array}{l}2015 \\
179\end{array}$} & \\
\hline \multirow{4}{*}{$\begin{array}{l}\text { Urban } \\
\text { participants }\end{array}$} & \multirow[t]{2}{*}{ Tougher sentences } & $\mathrm{n}$ & & & & & \\
\hline & & $\%$ & $52.1 \%$ & $42.7 \%$ & $47.6 \%$ & $35.7 \%$ & $44.5 \%$ \\
\hline & \multirow[t]{2}{*}{ Rehabilitation } & $\mathrm{n}$ & 245 & 327 & 263 & 323 & 1158 \\
\hline & & $\%$ & $47.9 \%$ & $57.3 \%$ & $52.4 \%$ & $64.3 \%$ & $55.5 \%$ \\
\hline \multirow{2}{*}{$\begin{array}{l}\text { Trend } \\
<.001\end{array}$} & \multirow[t]{2}{*}{ Total } & $\mathrm{n}$ & 512 & 571 & 502 & 502 & 2087 \\
\hline & & $\%$ & $100.0 \%$ & $100.0 \%$ & $100.0 \%$ & $100.0 \%$ & $100.0 \%$ \\
\hline
\end{tabular}

Table 7

\begin{tabular}{|c|c|c|c|c|}
\hline \multicolumn{2}{|c|}{$\begin{array}{l}\text { What is the best way to deal with young } \\
\text { offenders who commit violent crime? }\end{array}$} & Rural & Urban & Total \\
\hline \multicolumn{2}{|c|}{ Tougher sentences } & $1313(52.1)$ & $929(44.5)$ & $2391(48.8)$ \\
\hline \multicolumn{2}{|l|}{ Rehabilitation } & $1205(47.9)$ & $1158(55.5)$ & $2510(51.2)$ \\
\hline $\begin{array}{l}\text { Chi-sq 26.60, 1, p } \\
<.001\end{array}$ & Total & $2518(100)$ & $2087(100)$ & $4605(100)$ \\
\hline
\end{tabular}

The intensity of penal sanctions

As the data in Tables 8, 9 and 10 indicate, there was a significant relationship between where people live and the intensity of penal sanctions. The cross-tabulations revealed key differences on this measure, as evidenced by the difference in percentages between the rural and urban classifications. While both the rural and the urban heavily favored cracking down on criminals over ensuring their rights, it appears that people from rural areas are significantly more likely to support such measures. For example, in 200480.7 percent of rural respondents and 68.4 percent of urban respondents favored limiting rights. Notably, there is a significant trend in both classifications indicating that support for this statement has fallen consistently. For instance, by 2015 support for limiting the rights of offenders dropped to 64.1 percent of rural respondents and 51.3 percent of urban respondents. However, on this dimension, the difference between the rural and urban classification is not only significant across all years but has remained above 10 percent for each year surveyed. Indeed, the crosssectional data indicates that this difference remains significant over the decade with 73.1 
percent of rural respondents agreeing with this statement, in contrast to 61 percent of urban respondents. Thus, while both classifications appear to be losing an appetite for revoking the rights of offenders in the name of cracking down on crime, the gap between the classifications remains substantial.

Table 8

\begin{tabular}{|c|c|c|c|c|c|c|c|}
\hline \multirow{2}{*}{\multicolumn{3}{|c|}{$\begin{array}{l}\text { We must crack down on crime, even if } \\
\text { that means that criminals lose their } \\
\text { rights }\end{array}$}} & \multicolumn{4}{|l|}{ YEAR } & \multirow{3}{*}{$\begin{array}{l}\text { Total } \\
1841\end{array}$} \\
\hline & & & \multirow{2}{*}{$\begin{array}{l}2004 \\
542\end{array}$} & \multirow{2}{*}{$\begin{array}{l}2008 \\
640\end{array}$} & \multirow{2}{*}{$\begin{array}{l}2011 \\
404\end{array}$} & \multirow{2}{*}{$\begin{array}{l}2015 \\
255\end{array}$} & \\
\hline \multirow{4}{*}{$\begin{array}{l}\text { Rural } \\
\text { participants }\end{array}$} & \multirow[t]{2}{*}{ Agree } & $\mathrm{n}$ & & & & & \\
\hline & & $\%$ & $80.7 \%$ & $73.8 \%$ & $69.5 \%$ & $64.1 \%$ & $73.1 \%$ \\
\hline & \multirow[t]{2}{*}{ Disagree } & $\mathrm{n}$ & 130 & 227 & 177 & 143 & 677 \\
\hline & & $\%$ & $19.3 \%$ & $26.2 \%$ & $30.5 \%$ & $35.9 \%$ & $26.9 \%$ \\
\hline \multirow[t]{2}{*}{ Trend $<.001$} & \multirow[t]{2}{*}{ Total } & $\mathrm{n}$ & 672 & 867 & 581 & 398 & 2518 \\
\hline & & $\%$ & $\begin{array}{l}100.0 \\
\%\end{array}$ & $\begin{array}{l}100.0 \\
\%\end{array}$ & $\begin{array}{l}100.0 \\
\%\end{array}$ & $100.0 \%$ & $100.0 \%$ \\
\hline
\end{tabular}

Table 9

\begin{tabular}{|c|c|c|c|c|c|c|c|}
\hline \multirow{2}{*}{\multicolumn{3}{|c|}{$\begin{array}{l}\text { We must crack down on crime, even if } \\
\text { that means that criminals lose their } \\
\text { rights }\end{array}$}} & \multicolumn{4}{|l|}{ YEAR } & \multirow{3}{*}{$\begin{array}{l}\text { Total } \\
1258\end{array}$} \\
\hline & & & \multirow{2}{*}{$\begin{array}{l}2004 \\
350\end{array}$} & \multirow{2}{*}{$\begin{array}{l}2008 \\
369\end{array}$} & \multirow{2}{*}{$\begin{array}{l}2011 \\
285\end{array}$} & \multirow{2}{*}{2015} & \\
\hline \multirow{4}{*}{$\begin{array}{l}\text { Urban } \\
\text { participants }\end{array}$} & \multirow[t]{2}{*}{ Agree } & $\mathrm{n}$ & & & & & \\
\hline & & $\%$ & $68.4 \%$ & $64.6 \%$ & $56.8 \%$ & $50.6 \%$ & $61 \%$ \\
\hline & \multirow[t]{2}{*}{ Disagree } & $\mathrm{n}$ & 162 & 202 & 217 & 248 & 829 \\
\hline & & $\%$ & $31.6 \%$ & $35.4 \%$ & $43.2 \%$ & $49.4 \%$ & $39.0 \%$ \\
\hline \multirow[t]{2}{*}{ Trend $<.001$} & \multirow[t]{2}{*}{ Total } & $\mathrm{n}$ & 512 & 571 & 502 & 502 & 2087 \\
\hline & & $\%$ & $100.0 \%$ & $100.0 \%$ & $100.0 \%$ & $100.0 \%$ & $100.0 \%$ \\
\hline
\end{tabular}

Table 10

\begin{tabular}{|c|c|c|c|c|}
\hline \multicolumn{2}{|c|}{$\begin{array}{l}\text { We must crack down on crime, even if that } \\
\text { means that criminals lose their rights }\end{array}$} & Rural & Urban & Total \\
\hline \multicolumn{2}{|c|}{ Agree } & $1841(73.1)$ & $1258(61.0)$ & $3099(67.2)$ \\
\hline \multicolumn{2}{|l|}{ Disagree } & $677(26.9)$ & $829(39.0)$ & $1506(32.8)$ \\
\hline $\begin{array}{l}\text { Chi-sq 85.43, 1, p } \\
<.001\end{array}$ & Total & $2518(100)$ & $2087(100)$ & $4605(100)$ \\
\hline
\end{tabular}

Specified forms of penal sanctions

Finally, the data indicates there was a significant relationship between where people live and their views on the death penalty (see Tables 11, 12 and 13). Specifically, it appears that people from rural areas are more likely to support the death penalty while people from urban areas are more likely to oppose it. The cross-tabulations revealed key differences in support for the death penalty, as evidenced by the difference in percentages between the rural and urban classifications. 


\section{Punitive attitudes across geographical areas: Exploring the rural/urban divide in Canada- Mulrooney and Wise}

Notably, while the difference between the classifications are significant across the years, the most recent figures suggest that the gap between the urban and the rural appears to be growing. For example, in 200449.1 percent of rural respondents supported the death penalty for people convicted of murder in contrast to $42 \%$ of urban respondents, a seven percent difference. However, 2015 showed the greatest gulf between the classifications as 49 percent of rural respondents, in contrast to only 36.9 percent of urban respondents indicated their favor for the death penalty, an 11.3 percent difference.

Evidently, as a whole, rural respondents showed significantly greater support for, and therefore less opposition to, the death penalty across all years with an average of 47.3 percent in contrast to 39.6 percent in the urban. Notably, neither category shows a significant trend over the decade and support/opposition to the death penalty remains relatively stagnant.

Table 11

\begin{tabular}{|c|c|c|c|c|c|c|c|}
\hline \multicolumn{3}{|c|}{ Favour or oppose the death penalty } & \multicolumn{4}{|l|}{ YEAR } & \multirow{3}{*}{$\begin{array}{l}\text { Total } \\
1190\end{array}$} \\
\hline & & & 2004 & 2008 & 2011 & 2015 & \\
\hline \multirow{4}{*}{$\begin{array}{l}\text { Rural } \\
\text { participants }\end{array}$} & \multirow[t]{2}{*}{ Favour } & $\mathrm{n}$ & 330 & 404 & 261 & 195 & \\
\hline & & $\%$ & $49.1 \%$ & $46.6 \%$ & $44.9 \%$ & $49.0 \%$ & $47.3 \%$ \\
\hline & \multirow[t]{2}{*}{ Oppose } & $\mathrm{n}$ & 342 & 463 & 320 & 203 & 1328 \\
\hline & & $\%$ & $50.9 \%$ & $53.4 \%$ & $55.1 \%$ & $51.0 \%$ & $52.7 \%$ \\
\hline \multirow[t]{2}{*}{ Trend .65} & \multirow[t]{2}{*}{ Total } & $\mathrm{n}$ & 672 & 867 & 581 & 398 & 2518 \\
\hline & & $\%$ & $100.0 \%$ & $100.0 \%$ & $100.0 \%$ & $100.0 \%$ & $100.0 \%$ \\
\hline
\end{tabular}

Table 12

\begin{tabular}{|c|c|c|c|c|c|c|c|}
\hline \multicolumn{3}{|c|}{ Favour or oppose the death penalty } & \multicolumn{4}{|l|}{ YEAR } & \multirow{3}{*}{$\begin{array}{l}\text { Total } \\
827\end{array}$} \\
\hline & & & 2004 & 2008 & 2011 & 2015 & \\
\hline \multirow{4}{*}{$\begin{array}{l}\text { Urban } \\
\text { participants }\end{array}$} & \multirow[t]{2}{*}{ Favour } & $\mathrm{n}$ & 215 & 235 & 192 & 185 & \\
\hline & & $\%$ & $42.0 \%$ & $41.2 \%$ & $38.2 \%$ & $36.9 \%$ & $39.6 \%$ \\
\hline & \multirow[t]{2}{*}{ Oppose } & $\mathrm{n}$ & 297 & 336 & 310 & 317 & 1260 \\
\hline & & $\%$ & $58.0 \%$ & $58.8 \%$ & $61.8 \%$ & $63.1 \%$ & $60.4 \%$ \\
\hline \multirow[t]{2}{*}{ Trend .06 } & \multirow[t]{2}{*}{ Total } & $\mathrm{n}$ & 512 & 571 & 502 & 502 & 2087 \\
\hline & & $\%$ & $100.0 \%$ & $100.0 \%$ & $100.0 \%$ & $100.0 \%$ & $100.0 \%$ \\
\hline
\end{tabular}

Table 13

\begin{tabular}{|c|c|c|c|c|}
\hline \multicolumn{2}{|c|}{ Favour or oppose the death penalty } & Rural & Urban & Total \\
\hline \multicolumn{2}{|c|}{ Favour } & $1190(47.3)$ & $827(39.6)$ & $2017(43.5)$ \\
\hline \multicolumn{2}{|l|}{ Oppose } & $1328(52.7)$ & $1260(60.4)$ & $2588(56.5)$ \\
\hline $\begin{array}{l}\text { Chi-sq 27.01, 1, p } \\
<.001\end{array}$ & Total & $2518(100)$ & $2087(100)$ & $4605(100)$ \\
\hline
\end{tabular}

\section{Punitivity Index}

The punitivity index indicates that, when that data is taken together, the rural group is significantly more punitive than the urban group overall (see Tables 14, 15 and 16). Indeed, a significantly greater percentage of rural respondents fell into the more punitive distribution while a significantly greater percentage of urban respondents fell into the less punitive 
distribution. For instance, in 2004, 63.4 percent of rural respondents fell into the more punitive distribution compared to only 54.1 percent of urban respondents. Conversely, a significantly greater percentage of urban respondents fell into the less punitive distribution than rural respondents. For example, in 2015, 44 percent or rural respondents fell into this category compared to 59.8 percent of the urban respondents. Notably, when we collapse the cross-sectional data to explore the puntivity distribution over-time, we see a similar story: the rural holds significantly greater punitive attitudes than the urban at 59.8 percent and 48.4 percent respectively. However, while the urban indicates a significant trend towards decreasing levels of punitivity and increasing levels of moderation, the rural shows no significant trend.

Table 14

\begin{tabular}{|c|c|c|c|c|c|c|c|}
\hline \multicolumn{3}{|c|}{ Punitivity index } & \multicolumn{4}{|l|}{ YEAR } & \multirow{3}{*}{$\begin{array}{l}\text { Total } \\
1507\end{array}$} \\
\hline & & & \multirow{2}{*}{$\begin{array}{l}2004 \\
426\end{array}$} & \multirow{2}{*}{$\begin{array}{l}2008 \\
509\end{array}$} & \multirow{2}{*}{$\begin{array}{l}2011 \\
349\end{array}$} & \multirow{2}{*}{$\begin{array}{l}2015 \\
223\end{array}$} & \\
\hline Rural & \multirow[t]{2}{*}{ More punitive } & $\mathrm{n}$ & & & & & \\
\hline \multirow[t]{3}{*}{ participants } & & $\%$ & $63.4 \%$ & $58.7 \%$ & $60.1 \%$ & $56.0 \%$ & $59.8 \%$ \\
\hline & \multirow[t]{2}{*}{ Less punitive } & $\mathrm{n}$ & 246 & 358 & 232 & 175 & 1011 \\
\hline & & $\%$ & $36.6 \%$ & $41.3 \%$ & $39.9 \%$ & $44.0 \%$ & $40.2 \%$ \\
\hline \multirow[t]{2}{*}{ Trend .03 } & \multirow[t]{2}{*}{ Total } & $\mathrm{n}$ & 672 & 867 & 581 & 398 & 2518 \\
\hline & & $\%$ & $100.0 \%$ & $100.0 \%$ & $100.0 \%$ & $100.0 \%$ & $100.0 \%$ \\
\hline
\end{tabular}

Table 15

\begin{tabular}{|c|c|c|c|c|c|c|c|}
\hline \multicolumn{3}{|c|}{ Punitivity index } & \multicolumn{4}{|l|}{ YEAR } & \multirow{3}{*}{$\begin{array}{l}\text { Total } \\
1010\end{array}$} \\
\hline & & & \multirow{2}{*}{$\begin{array}{l}2004 \\
277\end{array}$} & \multirow{2}{*}{$\begin{array}{l}2008 \\
284\end{array}$} & \multirow{2}{*}{$\begin{array}{l}2011 \\
247\end{array}$} & \multirow{2}{*}{$\begin{array}{l}2015 \\
202\end{array}$} & \\
\hline \multirow{4}{*}{$\begin{array}{l}\text { Urban } \\
\text { participants }\end{array}$} & \multirow[t]{2}{*}{ More punitive } & $\mathrm{n}$ & & & & & \\
\hline & & $\%$ & $54.1 \%$ & $49.7 \%$ & $49.2 \%$ & $40.2 \%$ & $48.4 \%$ \\
\hline & \multirow[t]{2}{*}{ Less punitive } & $\mathrm{n}$ & 235 & 287 & 255 & 300 & 1077 \\
\hline & & $\%$ & $45.9 \%$ & $50.3 \%$ & $50.8 \%$ & $59.8 \%$ & $51.6 \%$ \\
\hline \multirow[t]{2}{*}{ Trend $<.001$} & \multirow[t]{2}{*}{ Total } & $\mathrm{n}$ & 512 & 571 & 502 & 502 & 2087 \\
\hline & & $\%$ & $100.0 \%$ & $100.0 \%$ & $100.0 \%$ & $100.0 \%$ & $100.0 \%$ \\
\hline
\end{tabular}

Table 16

\begin{tabular}{|l|l|l|l|}
\hline Punitivity Index & $\begin{array}{l}\text { Rural } \\
\mathrm{n}(\%)\end{array}$ & $\begin{array}{l}\text { Urban } \\
\mathrm{n}(\%)\end{array}$ & Total \\
\hline More punitive & $1507(59.8)$ & $1168(48.4)$ & $2675(54.6)$ \\
\hline Less punitive & $1011(40.2)$ & $1215(51.6)$ & $2226(45.4)$ \\
\hline Total & $2518(100)$ & $2383(100)$ & $4901(100)$ \\
\hline
\end{tabular}

Chi-square $=57.9,1, p<.001$

Bivariate analyses were also conducted on demographic variables of education, gender and age to determine associations with punitive attitudes. In chi square analyses education was significantly associated with punitive attitudes $(\mathrm{p}<.001)$ while the association with gender approached significance $(p=.06)$. Age was not significantly associated with punitive attitudes $(\mathrm{p}=.12)$. These results seem to replicate fairly consistently from study to study (see King \& Maruna, 2009; Roberts et al., 2012; Applegate, Cullen, \& Fisher, 2002). 


\section{Punitive attitudes across geographical areas: Exploring the rural/urban divide in Canada- Mulrooney and Wise}

A logistic regression analysis was performed to determine independent predictors of punitive attitudes (see Table 17). Gender, education and age were including in the model. Controlling for age, gender and education, the residential location of participants is still clearly associated with attitudes to punitiveness. People from urban locations were 1.27 times more likely to have less punitive attitudes than people in rural locations. However, education does appear to play a significant role. Compared to people with up to a high-school level education, those with a college education were 1.66 times more likely to have less punitive attitudes while university educated were more than four times more likely to have less punitive attitudes. Gender was associated with punitive attitudes with females being slightly more likely to have less punitive attitudes. Once again, age was not associated with level of punitiveness.

Table 17

\begin{tabular}{|c|c|c|c|}
\hline Logistic Regression & B(S.E) & $\operatorname{Exp}(B)$ & Sig. \\
\hline Location (urban) & $.24(.07)$ & 1.27 & $<.001$ \\
\hline Gender (female) & $.13(.07)$ & 1.14 & .05 \\
\hline $\begin{array}{l}\text { Education up to high school } \\
\text { (Ref) }\end{array}$ & & 1.00 & \\
\hline College or some university & $.51(.09)$ & 1.66 & $<.001$ \\
\hline $\begin{array}{l}\text { Completed bachelor degree or } \\
\text { higher }\end{array}$ & $1.53(.08)$ & 4.62 & $<.001$ \\
\hline Age & $-.002(.002)$ & 1.002 & .39 \\
\hline
\end{tabular}

\section{Conclusion}

The data suggests that Canadians have mixed views on questions of punishment, showing support or a lack thereof for punitive and non-punitive measures alike. However, when we hone in, the data indicates significant variations dependent upon geographical location across all dimensions of punitiveness. With regards to the goals of punishment, the rural favoured punishing violent young offenders significantly more than the urban. While both classifications favoured limiting the rights of offenders in the name of cracking down on crime, the rural support was significantly greater than that of the urban. Finally, the rural support of the death penalty was significantly greater than the urban classifications.

Furthermore, the punitivity index indicates that, holistically, the rural holds much greater punitive attitudes than the urban. While education appears to play a role in the development of punitive attitudes across the sample, when controlling for education, age and gender, the residential location of participants remains strongly associated with punitive attitudes. Notably, while the data indicates a significant trend towards a decrease in punitive attitudes in Canada as a whole, no significant trend appears in the rural. Subsequently, as the urban is driving reductions in punitive attitudes, the gap between the rural and urban appears to be growing.

Webster and Doob (2015) theorised that through a decade of the Conservative government's repeated valorisation of punitive values, the underlying normative structure of Canadian society may have begun to change. However, the data presented in this article suggests that, in aggregate, Canadians appear to be becoming less punitive even during this decade of penal populism. In this regard, it is also important to note once again that, in contrast to other countries where penal populism has tended to dominant political life, in 
Canada the Conservatives constituted only one voice among many as there were loud pockets of resistance to this 'new punitiveness', especially in the media, legal and, to a lesser extent, political spheres (Mulrooney, 2018). For example, Mulrooney (2018) has previously argued that the overwhelming presence of a counter discourse in the media specifically meant not only that the public arena was not saturated with populist discourse alone, but also that the public was presented with an alternative perspective from which they could form opinions and perceptions surrounding issues of crime and punishment.

At the same time, the fact that this overall reduction in punitive attitudes was led by the urban is perhaps not all that surprising when we consider that those who live in rural communities in Canada tend to support conservative parties (Roy, Perrella \& Borden, 2015) and that part of the explanation may lie in differences in attitudes towards punishment and within perspectives of morality more broadly (Cutler \& Jenkins, 2000). This reinforces the need to differentiate between penal culture, and how this may be shaped by national identity (in the macro sense) and 'penal cultures' (in the micro sense), which may be further shaped by identification with or allegiance to a more regionalised, localised and individualised identities.

With this in mind, in an effort to explore why it is that the rural areas tend to hold more punitive attitudes than the urban, future research should seek to move beyond the demographic factors controlled for here and explore a number of variables which have been correlated with punitive attitudes and punitiveness more broadly. For instance, fear of crime (see Kury, 2008; Kury \& Winterdyk, 2013; Armborst, 2017), the perceptions that crime is rising (Garland, 2001, 2013; Costelloe, Chiricos \& Gertz, 2009) and a lack of confidence in the criminal justice system (Chapman, Mirrlees-Black \& Brawn, 2002; Jones \& Weatherburn, 2010; Caplow \& Simon, 1999; Tonry, 2004; Pratt \& Clark, 2005) have also been shown to increase punitivity. Additionally, Durkheimian notions of trust and solidarity (see Kennedy, 2000; Pratt \& Eriksson, 2013; Karstedt, 2014, 2015) as well as individual values such as one's religiosity (Unnever, Cullen \& Applegate, 2005; Unnever, Cullen \& Bartkowski, 2006; Baker \& Booth, 2016) or political allegiances (Tonry, 1999; Jacobs \& Helms, 1996; Beckett \& Western, 2001; Smith, 2004; Yates \& Fording, 2005; Loader \& Sparks, 2016) have likewise been shown to shape punitive attitudes (Lappi-Seppälä, 2008, 2011, 2012). Importantly, these variables themselves and their relationship to punitive attitudes are no doubt closely related to geography (see Gray \& O'Connor, 1990; Yarwood \& Gardnner, 2000).

With consideration to political values specifically, the (growing) gap between the urban/rural on punitivity aligns with the notion that the urban/rural divide is one of the greatest political fault lines in present day politics. Indeed, there are a variety of sociocultural and economic explanations for why the rural may be 'primed for populism' (see Goldman et al., 2018; Cox, Lienesch \& Jones, 2017). In the Canadian context particularly, the growing population concentration in a small number of major urban centres and the subsequent consolidation of economic, political and social power has exacerbated this disconnect in recent years (Speer \& Jivani, 2017). To this end, future research should focus attention on exploring the nexus between punitive attitudes and aspects of populist appeal in the urban/rural context more generally (Bialik, 2018; Beckett, 2016). For instance, punitive attitudes have been positively correlated with economic insecurity, particularly among white males who are less well educated and earn less income (Costelloe et al, 2009), and punitiveness at the micro and macro level has been linked to negative views of immigrants 


\section{Punitive attitudes across geographical areas: Exploring the rural/urban divide in Canada- Mulrooney and Wise}

and immigration (see von Hofer, 2003; Ruddell, 2005; Unnever \& Cullen, 2010; Brown \& Piscitelli, 2016).

Theoretically speaking, the premise is that the penal populism which became dominant in many Western countries in the 1990s and through the 2000s served as the foundations of the more general resurgence of political populism in the early twenty first century (see Pratt \& Miao, 2017). Indeed, penal populism represents an attack on reason, and by proxy on the experts, elites and 'soft-on-crime' politicians who advance penal moderation, in the name of a 'common sense' and democratized approach to crime and punishment. Likewise, political populism brings a similar political logic, with the target often being corrupt liberal elites more generally represented by, for example, rhetoric around 'draining the swamp' or 'liberal elites' contrasted to the 'the pure and noble people' (Mudde, 2004; Judis, 2016). Notably, the right-wing variations of these populisms, which have dominated the politics of law and order and have been most successful thus far in recent Western contexts, not only champion 'the people' but tend to do so against an elite they accuse of coddling a third group whether that third group be, for instance, immigrants or refugees in the context of political populism or offenders in the case of penal populism.

This shared political logic, the presence of a freer flowing political populism (Pratt \& Miao, 2017) and the political gulf between the urban and the rural suggests that answers as to why it is that the rural holds more punitive attitudes than the urban may be found by exploring this phenomenon as a commitment to a broader political project (see Roy, Perrella $\&$ Borden, 2015). Indeed, as Loader and Sparks (2016, p. 316) suggest, "disputes over crime and its control are inescapably entangled with wider questions about the power and limits of authority, the allocation of social goods and the terms of collective coexistence".

The empirical effort then is to tease out particular values that are called upon and inform attitudes towards crime and punishment, to delineate whether or not these attitudes are related to populist thinking more broadly, and in what ways signify a shared political logic and commitment between penal populism and political populism, and ultimately how this contributes to the urban/rural divide as one of the greatest political fault lines in present day politics.

\section{References}

Adams M. (2014, 2 September). Crime and populism. Policy Options, 35(5), 67-71. Retrieved from http://policyoptions.irpp.org/wpcontent/uploads/sites/2/2014/08/adams.pdf

Adams, C. (2008). Politics in Manitoba: Parties, leaders, and voters. Winnipeg, MB: University of Manitoba Press.

Adriaenssen, A., and Aertsen, I. (2015). Punitive attitudes: Towards an operationalization to measure individual punitivity in a multidimensional way. European Journal of Criminology, 12(1), 92-112. https://doi.org/10.1177/1477370814535376

Alasia, A., Bédard, F., Bélanger, J., Guimond, E. and Penney, C. (2017). Measuring remoteness and accessibility: A set of indices for Canadian communities. Ottawa, ON: Statistics Canada. 
Applegate, B.K., Cullen F.T., Turner, M.G., and Sundt, J.L. (1996). Assessing public support for three-strikes-and you're-out laws: Global versus specific attitudes. Crime \& Delinquency, 42(4), 517-535. https://doi.org/10.1177/0011128796042004002

Applegate, B.K. Cullen F.T. and Fisher, B.S. (2002). Public views toward crime and correctional policies: Is there a gender gap? Journal of Criminal Justice, 30(2), 89100. https://doi.org/10.1016/S0047-2352(01)00127-1

Armborst, A. (2017). How fear of crime affects punitive attitudes. European Journal on Criminal Policy and Research, 23(3), 461-48. https://doi.org/10.1007/s10610-0179342-5

Baker, J. and Booth, J. (2016). Hell to pay: Religion and punitive ideology among the American public. Punishment and Society, 18(2), 151-176. https://doi.org/10.1177/1462474516635886

Beckett, A. (2016, 13 December). From Trump to Brexit, power has leaked from cities to the countryside. The Guardian. Retrieved from https://www.theguardian.com/commentisfree/2016/dec/12/trump-brexit-citiescountryside-rural-voters

Beckett, K. and Western, B. (2001). Governing social marginality: Welfare, incarceration and the transformation of state policy. Punishment and Society, 3(1), 43-59. https://doi.org/10.1177/14624740122228249

Bialik, K. (2018). Key findings about American life in urban, suburban and rural areas, Pew Research Centre. Retrieved from https://www.pewresearch.org/facttank/2018/05/22/key-findings-about-american-life-in-urban-suburban-and-rural-areas/

Bittner, A. (2007). The effects of information and social cleavages: Explaining issue attitudes and vote choice in Canada. Canadian Journal of Political Science, 40(4), 935-968. https://doi.org/10.1017/S000842390707117X

Blais, A., Gidengil, E., Nadeau, R. and Nevitte, N. (2002). Anatomy of a liberal victory: Making sense of the vote in the 2000 Canadian election. Peterborough, ON: Broadview Press.

Bricker, D. and Ibbitson, J. (2013). The Big Shift: The seismic change in Canadian politics, business, and culture and what it means for our future. Toronto, ON: Harper Collins.

Brown, S.D. and Piscitelli, A. (2016). A "criminal immigrant" mindset and punitiveness: The Canadian case. International Journal of Criminology and Sociological Theory, 9(2), $1-18$.

Burke, D. (2000, 8 March). Australians support NT laws [Press release]. Northern Territory Government, p. 1.

Caplow, T. and Simon, J. (1999). Understanding prison policy and population trends. Crime and Justice, 26, 63-120. https://doi.org/10.1086/449295 


\section{Punitive attitudes across geographical areas: Exploring the rural/urban divide in Canada- Mulrooney and Wise}

Chapman, B., Mirrlees-Black, C. and Brawn, C. (2002). Improving public attitudes to the criminal justice system: the impact of information. Home Office Research Study, 245. https://doi.org/10.1037/e454602008-001

Cooke, M. (2018). Implications of global peak population for Canada's future: Northern, rural and remote communities. Canadian Studies in Population, 45(1-2), 55-61. https://doi.org/10.25336/csp29375

Costelloe, M., Chiricos. T. and Gertz, M. (2009). Punitive attitudes toward criminals: Exploring the relevance of crime salience and economic insecurity. Punishment and Society, 11(1), 25-39. https://doi.org/10.1177/1462474508098131

Cox, D., Lienesch, R. and Jones, R.P. (2017). Beyond economics: Fears of cultural displacement pushed the white working class to Trump. Public Religion Research Institute (PPRI). Retrieved from https://www.prri.org/research/white-working-classattitudes-economy-trade-immigration-election-donald-trump/

DeKeseredy, W.S., Donnermeyer, J.F., Schwartz, M.D., Tunnell, K.D. and Hall, M. (2007). Thinking critically about rural gender relations: Toward a rural masculinity crisis/male peer support model of separation/divorce sexual assault. Critical Criminology, 15(4), 295-311. https://doi.org/10.1007/s10612-007-9038-0

Dodd., S. (2017). The punitive woman? Gender differences in public attitudes toward parole among an Australian sample. The International Journal of Offender Therapy and Comparative Criminology, 62(10), 3006-3022. https://doi.org/10.1177/0306624X17739560

Donnermeyer, J.F. and DeKeseredy, W.S. (2014). Rural criminology. New York, NY: Routledge. https://doi.org/10.4324/9780203094518

Donnermeyer, J.F., Jobes, P. and Barclay, E. (2006). Rural crime, poverty, and community. In W.S. DeKeseredy and B. Perry. Lanham (Eds.), Advancing critical criminology: Theory and application (pp. 199-218). Lanham, MD: Lexington Books

Doob, A.N. and Roberts, J.V. (1983). An analysis of the public's view of sentencing. Ottawa, ON: Department of Justice, Canada.

Doob, A.N. and Roberts, J.V. (1988). Public punitiveness and public knowledge of the facts: Some Canadian surveys. In N. Walker and M. Hough (Eds.). Public attitudes to sentencing: Surveys from five countries (pp. 111-133). Aldershot, UK: Gower.

Doob, A.N. (2016). A values and evidence approach to sentencing purposes and principles. Research and Statistics Division, Department of Justice Canada. Retrieved from https://www.justice.gc.ca/eng/rp-pr/jr/vea-avp/vea-avp-eng.pdf

Doob, A.N., Sprott, J.B., Marinos, V. and Varma, K.N. (1998). An exploration of Ontario residents' views of crime and the criminal justice system. Toronto, ON: Centre of Criminology, University of Toronto.

Downes, D. (1988). Contrasts in Tolerance. Oxford, UK: Oxford University Press. 
Flanagan, T. (2009). Harper's team: Behind the scenes in the conservative rise to power (2nd edn). Montreal, QC: McGill-Queen's University Press.

Garland, D. (2001). The culture of control: Crime and social order in contemporary society. Chicago, IL: University of Chicago Press. https://doi.org/10.7208/chicago/9780226190174.001.0001

Garland, D. (2013). Penality and the penal state. Criminology, 51(3), 475-517. https://doi.org/10.1111/1745-9125.12015

Gelb, K. (2008). Myths and misconceptions: Public opinion versus public judgment about sentencing. In A. Freiburg and K. Gelb (Eds.), Penal populism, sentencing councils and sentencing policy. Devon, UK: Willan Publishing. https://doi.org/10.4324/9781315820095

Gelb, K. (2011). Predictors of punitiveness: Community views in Victoria. Melbourne, Vic: Sentencing Advisory Council. Retrieved from https://www.sentencingcouncil.vic.gov.au/sites/default/files/publicationdocuments/Predictors $\% 20$ of $\% 20$ Punitiveness $\% 20$ Community $\% 20$ Views $\% 20 \operatorname{In} \% 20 \mathrm{~V}$ ictoria.pdf

Gerber, J. and Engelhardt-Greer, S. (1996). Just and painful: Attitudes toward sentencing criminals. In T.J. Flanagan and D.R. Longmire (Eds.). Americans view crime and justice: A national public opinion survey (pp. 62-74). Thousand Oaks, CA: Sage Publications. https://doi.org/10.4135/9781483326900.n5

Gidengil, E., Blais, A., Nevitte, N. and Nadeau, R. (2010). Citizens. In W. Cross (Ed.). Auditing Canadian Democracy (pp. 93-117). Vancouver, BC: University of British Columbia Press.

Goldman, L., Lim, M.P., Chen, Q., Jin, P., Muennig, P. and Vagelos, A. (2018). Independent relationship of changes in death rates with changes in US presidential voting. Journal of General Internal Medicine, 34(3), 363-371. https://doi.org/10.1007/s11606-0184568-6

Granatstein, J.L. (1982). The Ottawa Men: The civil service mandarins 1935-1957. Oakville, ON: Rock's Mills Press.

Grasmick, H.G., Bursik, R.J. and Blackwell, B. (1993). Religious beliefs and public support for the death penalty for juveniles and adults. Journal of Crime and Justice, 16(2), 5986. https://doi.org/10.1080/0735648X.1993.9721494

Gray, D.E. and O'Connor, M.E. (1990). Concern about and fear of crime in an Australian rural community. The Australian and New Zealand Journal of Criminology, 23(4), 284-298. https://doi.org/10.1177/000486589002300407

Green, D. (2008). When children kill children. Penal populism and political culture. New York, NY: Oxford University Press. https://doi.org/10.1093/acprof:oso/9780199230969.001.0001 


\section{Punitive attitudes across geographical areas: Exploring the rural/urban divide in Canada- Mulrooney and Wise}

Hough, M. and Roberts, J.V. (2002). Public knowledge and public opinion of sentencing. In C. Tata and N. Hutton (Eds.), Sentencing and society: International perspectives (pp. 157-176). Aldershot, UK: Ashgate.

Jacobs, D. and Helms, R.E. (1996). Towards a political model of incarceration: A time-series examination of multiple explanations for prison admission rates. American Journal of Sociology, 102(2), 323-357. https://doi.org/10.1086/230949

Jenkins, R.W. and Cutler, F. (2001). Where one lives and what one thinks: Implications of rural-urban opinion cleavages for Canadian federalism. State of the Federation 2001. Kingston, ON: Institute of Intergovernmental Affairs.

Jones, C. and Weatherburn, D. (2010). Public confidence in the NSW criminal justice system: a survey of the NSW public. Australian and New Zealand Journal of Criminology, 43(3), 506-525. https://doi.org/10.1375/acri.43.3.506

Judis, J.B. (2016). The populist explosion. How the great recession transformed American and European politics. New York, NY: Columbia Global Reports.

Kanji, M., Bilodeau, A. and Scotto, T. (2012). The Canadian Election Studies, Assessing Four Decades of Influence. Vancouver, BC: UBC Press.

Karstedt, S. (2014). Europe as a normative power: Cultural peers and penal policies. In V. Kiss (Ed.), Beyond punitiveness: Crime and crime control in Europe in a comparative perspective. Budapest: Hungarian Society of Criminology.

Karstedt, S. (2015). Trust in transition: Legitimacy of criminal justice in transitional societies. In G. Mesko and J. Tankebe (Eds.). Trust and legitimacy in criminal justice: European perspectives (pp. 3-31). New York, NY: Springer. https://doi.org/10.1007/978-3-319-09813-5_1

Kennedy, J. (2000). Monstrous offenders and the search for solidarity through modern punishment. Hastings Law Journal, 51(5), 829.

King, A. and Maruna, S. (2009). The function of fiction for a punitive public. In Y. Jewkes (Ed.). Crime and Media. Volume 1: Theorizing Crime and Media (pp. 16-30). London, UK: Sage Publications.

Kristof, N. (2017, 4 February). Canada, Leading the Free World. Retrieved from https://www.nytimes.com/2017/02/04/opinion/sunday/canada-leading-the-freeworld.html?mcubz=3.

Kugler, M.B., Funk, F., Braun, J., Gollwitzer, M., Kay, A.C. and Darley, J.M. (2013). Differences in punitiveness across three cultures: A test of American exceptionalism in justice attitudes. The Journal of Criminal Law \& Criminology, 103(4), 1071-1113.

Kury, H. (2008). Fear of crime - punitivity. New developments in theory and research. Bochum: Universitätsverslag Brockmeyer.

Kury, H. and Obergfell-Fuchs, J. (2008). Punitivity in Germany: Attitudes to punishment, sentencing and prison rates. In H. Kury and T.N. Ferdinand (Eds.), International Perspectives on Punitivity. Bochum: Universitätsverslag Brockmeyer. 
Kury, H. and Winterdyk, J. (2013). Fear of crime and punitiveness. Results from international student surveys. Bochum: Universitätsverslag Brockmeyer.

Kury, H., Kania, H. and Obergfell-Fuchs, J. (2004). Worüber sprechen wir, wenn wir über Punitivität sprechen? Versuch einer Konzeptionellen und empirischen Begriffsbestimmung. Kriminologisches Journal, 36(8), 51-88.

Lappi- Seppälä, T. (2012). Explaining national differences in the use of imprisonment. In S. Snacken and E. Dumortier (Eds.), Resisting punitiveness in Europe? Welfare, human rights and democracy. London, UK: Routledge.

Lappi-Seppälä, T. (2008). Trust, welfare, and political culture: Explaining differences in national penal policies. Crime and Justice, 37(1), 313-387.

https://doi.org/10.1086/525028

Lappi-Seppälä, T. (2011). Explaining imprisonment in Europe. European Journal of Criminology, 8(4), 303-328. https://doi.org/10.1177/1477370811411459

Liberty moves north. (2016, 29 October). The Economist. Retrieved from https://www.economist.com/news/leaders/21709305-it-uniquely-fortunate-manywaysbut-canada-still-holds-lessons-other-western

Loader, I. (2006). Fall of the platonic guardians: Liberalism, criminology, and political responses to crime in England and Wales. British Journal of Criminology, 46(4), 561586. https://doi.org/10.1093/bjc/azi091

Loader, I. and Sparks, R. (2016). Ideologies and crime: Political ideas and the dynamics of crime control. Global Crime, 17(3-4), 314-330. https://doi.org/10.1080/17440572.2016.1169926

Lyman, R. (2016, 6 December). Like Trump, Europe's populist win big with rural voters. The New York Times. Retrieved from https://www.nytimes.com/2016/12/06/world/europe/europe-poland-populism-ruralvoters.html

Macfarlane, E. (2017). "You can't always get what you want": Regime politics, the Supreme Court of Canada, and the Harper Government. The Canadian Journal of Political Science, 51(1), 1-21. https://doi.org/10.1017/S0008423917000981

Mackinnon, W. (2007). The 2007 provincial election in Prince Edward Island. Canadian Political Science Review, 1(2), 69-74.

Marche, S. (2016, 1 November). Canadian exceptionalism. Open Canada. Retrieved from https://www.opencanada.org/features/canadian-exceptionalism/

Marland, A. (2007). The 2007 provincial election in Newfoundland and Labrador. Canadian Political Science Review, 1(2), 75-85

Matthews, R. (2005). The myth of punitiveness. Theoretical Criminology, 9(2), 175-201. https://doi.org/10.1177/1362480605051639 


\section{Punitive attitudes across geographical areas: Exploring the rural/urban divide in Canada- Mulrooney and Wise}

Meyer J. and O’Malley P. (2005). Missing the punitive turn? Canadian criminal justice, 'balance' and penal modernism. Sydney Law School, Legal Studies Research Paper 09/95. Retrieved from https://papers.ssrn.com/sol3/papers.cfm?abstract_id=1475038

Mitchell, B. and Roberts, J.V. (2012). Sentencing for murder: Exploring public knowledge and public opinion in England and Wales. British Journal of Criminology, 52(1), 141158. https://doi.org/10.1093/bjc/azr073

Mudde, C. (2004). The populist zeitgeist. Government and Opposition, 39(4), 542-563. https://doi.org/10.1111/j.1477-7053.2004.00135.x

Mulrooney, K.J.D. (2018). Resisting the politics of punishment: Political culture and the evolution of canadian criminal justice policy (doctoral dissertation). The University of Kent/Universität Hamburg. Retrieved from https://kar.kent.ac.uk/67338/

Mulrooney, K.J.D. (forthcoming). Resisting the politics of punishment: Political culture and the evolution of Canadian criminal justice policy. London, UK: Routledge.

Owram, D. (1986). The Government Generation: Canadian intellectuals and the state, 19001945. Toronto, ON: University of Toronto Press. https://doi.org/10.3138/9781487578398

Pal, M. and Choudhry, S. (2007). Is every ballot equal? Visible minority vote dilution in Canada. IRPP Choices, 13(1), 3-27.

Pal, M. and Choudhry, S. (2014). Still not equal? Visible minority vote dilution in Canada. Canadian Political Science Review, 8(1), 85-101.

Pfaff, J. (2017). Locked In: The true cause of mass incarceration and how to achieve real reform. New York, NY: Basic Books.

Pfeiffer, C., Windzio, M. and Kleimann, M. (2005). Media use and its impacts on crime perception, sentencing attitudes and crime policy. European Journal of Criminology 2(3), 259-285. https://doi.org/10.1177/1477370805054099

Pratt, J. (2007). Penal populism. London, UK: Routledge. https://doi.org/10.4324/9780203963678

Pratt, J. and Clark, M. (2005). Penal populism in New Zealand. Punishment and Society, 7(3), 303-322. https://doi.org/10.1177/1462474505053831

Pratt, J. and Eriksson, A. (2013). Contrasts in punishment: An explanation of Anglophone excess and Nordic exceptionalism. London, UK: Routledge.

https://doi.org/10.4324/9780203096116

Pratt, J. and Miao, M. (2017). Penal populism: The end of reason. The Chinese University of Hong Kong Faculty of Law Research Paper No. 2017-02. Nova Criminis, 9(13), 71105.

Ramirez, M.D. (2013). Punitive sentiment. Criminology, 51(2), 329-364. https://doi.org/10.1111/1745-9125.12007 
Robbers, M. (2006). Tough-mindedness and fair play: Personality traits as predictors of attitudes toward the death penalty - an exploratory gendered study. Punishment and Society, 8(2), 203-222. https://doi.org/10.1177/1462474506062104

Roberts J.V., Hough, M., Jacobson, J. and Moon, N. (2009). Public attitudes to sentencing purposes and sentencing factors: An empirical analysis. Criminal Law Review, 11(11), 771-782.

Roberts, J.V. and Sprott, J. (2008). Exploring the differences between punitive and moderate penal policies in the United States and Canada. In H. Kury and T. Ferdinand (Eds.), International perspectives on punitivity. Bochum: Universitätsverslag Brockmeyer.

Roberts, J.V, and Doob, A.N. (1989). Sentencing and public opinion: Taking false shadows for true substances. Osgoode Hall Law Journal, 27, 491-515.

Roberts, J.V., Hough, M., Jackson, J. and Gerber, M. (2012). Public opinion towards the lay magistracy and the sentencing council guidelines: The effects of information on attitudes. British Journal of Criminology, 52(6), 1072-1091. https://doi.org/10.1093/bjc/azs024

Roberts, J.V. (2004). The virtual prison: Community custody and the evolution of imprisonment. Cambridge, UK: Cambridge University Press. https://doi.org/10.1017/CBO9780511520976

Roberts, J.V. and Hough, M. (2001). Public opinion, sentencing and parole: International trends. In R. Roesch, R. Corrado and R. Dempster (Eds.), Psychology in the courts: International advances in knowledge. Amsterdam: Harwood Academic.

Roberts, J.V. and Hough, M. (2005). Understanding public attitudes to criminal justice. Maidenhead, UK: Open University Press.

Roberts, J.V., Crutcher, N. and Verbrugge, P. (2007). Public attitudes to sentencing in Canada: Exploring Recent Findings. Canadian Journal of Criminology and Criminal Justice, 49(1), 75-107. https://doi.org/10.3138/U479-1347-3PL8-5887

Roy, J., Perrella, A.M.L. and Borden, J. (2015). Rural, suburban and urban voters: Dissecting residence based voter cleavages in provincial elections. Canadian Political Science Review, 9(1), 112-127.

Ruddell, R. (2005). Social disruption, state priorities, and minority threat: A cross-national study of imprisonment. Punishment and Society, 7(1), 7-28. https://doi.org/10.1177/1462474505048131

Smith, K.B. (2004). The politics of punishment: Evaluating political explanations of incarceration rates. The Journal of Politics, 66(3), 925-938. https://doi.org/10.1111/j.1468-2508.2004.00283.x

Speer, S. and Jivani, J. (2017, 5 June). The urban/rural divide and a more inclusive Canada. Policy Options. Retrieved from https://policyoptions.irpp.org/magazines/june2017/the-urbanrural-divide-and-a-more-inclusive-canada/ 


\section{Punitive attitudes across geographical areas: Exploring the rural/urban divide in Canada- Mulrooney and Wise}

Sprott, J. (1996). Understanding public views of youth crime and the youth justice system. Canadian Journal of Criminology, 38(3), 271-290.

Sprott, J. (1998). Understanding public opposition to a separate youth justice system. Crime and Delinquency, 44(3), 399-411. https://doi.org/10.1177/0011128798044003004

Sprott, J. (1999). Are members of the public tough on crime?: The dimensions of public punitiveness. Journal of Criminal Justice, 27(5), 467-474.

https://doi.org/10.1016/S0047-2352(99)00017-3

Tharoor, I. (2018, 9 August). The growing urban-rural divide in global politics. The Washington Post. Retrieved from https://www.washingtonpost.com/world/2018/08/09/growing-urban-rural-divideglobal-politics/?noredirect $=$ on\&utm_term $=$. a045e 6805943

The last liberals. (2016, 29 October). The Economist. Retrieved from https://www.economist.com/news/briefing/21709291-why-canada-still-easeopenness-last-liberals

Tonry, M. (1999). Parochialism in US sentencing policy. Crime and Delinquency, 45(1), 4865. https://doi.org/10.1177/0011128799045001003

Tonry, M. (2004). Thinking about crime: Sense and sensibility in American penal culture. New York, NY: Oxford University Press.

Unnever, J., Cullen, F. and Applegate, B.K., (2005). Turning the other cheek: Reassessing the impact of religion on punitive ideology. Justice Quarterly, 22(3), 204-339. https://doi.org/10.1080/07418820500089091

Unnever, J., Cullen, F. and Bartkowski, J. (2006). Images of god and public support for capital punishment: Does a close relationship with a loving god matter? Criminology, 44(4), 835-866. https://doi.org/10.1111/j.1745-9125.2006.00065.x

Unnever, J.D., Cullen, F.T. and Roberts J.V. (2005). Not everyone strongly supports the death penalty: Assessing weakly-held attitudes about capital punishment. American Journal of Criminal Justice, 29(2), 187-216. https://doi.org/10.1007/BF02885735

Unnever, J.D. and Cullen, F.T. (2010). The social sources of Americans' punitiveness: A test of three competing models. Criminology, 48(1), 99-129. https://doi.org/10.1111/j.1745-9125.2010.00181.x

Van Dijk, J. van Kersteren, J. and Smit. (2007). Criminal victimization in international perspective: key findings from the 2005-2005 ICVS and EU ICS. Tilburg: Tilburg University.

Von Hofer, H. (2003). Prison populations as political constructs: The case of Finland, Holland and Sweden. Journal of Scandinavian Studies in Criminology and Crime Prevention, 4(1), 21-38. https://doi.org/10.1080/14043850310009921

Walker, J., Collins. M. and Wilson, P. (1987). How the public sees sentencing: an Australian survey. Australian Institute of Criminology. Retrieved from https://aic.gov.au/file/5879/download?token=bXvOUtBf 
Webster, C.M. and Doob, A.N. (2007). Punitive trends and stable imprisonment rates in Canada. In M. Tonry (Ed.), Crime and Justice: A review of Literature (Vol. 36). Chicago, IL: University of Chicago Press.

Webster, C.M. and Doob, A.N. (2015). US punitiveness 'Canadian style'? Cultural values and Canadian punishment policy. Punishment and Society, 17(3), 299-321. https://doi.org/10.1177/1462474515590893

Weisheit, R.A., Falcone, D.N. and Wells, L.E. (3rd Eds.). (2006). Crime and policing in rural and small-town America (3rd edn). Prospect Heights, IL: Waveland Press.

Yarwood. R. and Gardner, G. (2000). Fear of crime, cultural threat and the countryside. Area, 32(4), 403-411. https://doi.org/10.1111/j.1475-4762.2000.tb00156.x

Yates, J. and Fording, R.C. (2005). Politics and state punitiveness in black and white. The Journal of Politics, 67(4), 1099-1121. https://doi.org/10.1111/j.14682508.2005.00352.x

Young, R.L. (1992). Religious orientation, race and support for the death penalty. Journal for the Scientific Study of Religion, 31(1), 76-87. https://doi.org/10.2307/1386833 